Fig. 1. Death rate increment due to COVID-2019 throughout the world. ${ }^{5}$

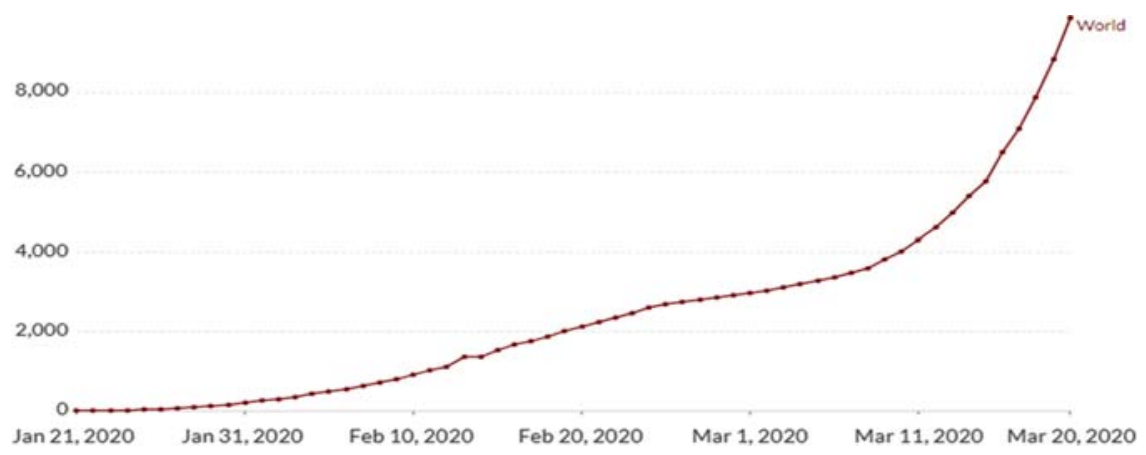

for treatment and safety. In India, the death rate and the recovery rate indicate that the pandemic is being controlled, largely because of the preparation done by government before COVID-19 reached more advanced stages. The numbers of laboratories, test kits, and medical facilities have been enhanced appropriately. The Indian government is collaborating with SAARC countries to fight this pandemic. Because the Indian government has taken the appropriate actions outlined here, the COVID-19 pandemic, although tragic, will have the best possible outcome in India.

\section{Acknowledgments.}

Financial support. No financial support was provided relevant to this article.

Conflicts of interest. All authors report no conflicts of interest relevant to this article.

\section{References}

1. Naming the 2019 coronavirus. International Committee on Taxonomy of Viruses website. https://talk.ictvonline.org/. Published February 11, 2020. Accessed April 30, 2020.
2. Five coronavirus cases confirmed in the US. The Jewish Voice website. http://thejewishvoice.com/2020/01/5-coronavirus-cases-confirmed-in-us/. Published January 27, 2020. Accessed April 30, 2020.

3. Fan Y, Zhao K, Shi Z-L, Zhou P. Bat coronaviruses in China. Viruses 2019; 11:210.

4. Coronavirus disease 2019 (COVID-19) situation report - 57. World Health Organization website. https://www.who.int/docs/default-source/coronaviruse/ situation-reports/20200317-sitrep-57-covid19.pdf?sfvrsn=a26922f2_4. Published March 17, 2020. Accessed April 30, 2020.

5. Statistics and research: coronavirus pandemic (COVID-19). Our World in Data website. https://ourworldindata.org/coronavirus-source-data. Accessed April 30, 2020.

6. Ministry of Health and Family Welfare website. https://www.mohfw.gov.in/. Accessed April 30, 2020.

7. Coronavirus (Covid-19) tracker India: Maharashtra, Delhi, Gujarat account for $52 \%$ cases in India. India Today website. https://www. indiatoday.in/india/story/coronavirus-cases-in-india-covid19-states-citiesaffected-1653852-2020-03-09. Published March 9, 2020. Accessed April 30, 2020.

8. Kampf G, Todt D, Pfaender S, Steinmann E. Persistence of coronaviruses on inanimate surfaces and its inactivation with biocidal agents. J Hosp Infect 2020;20:1-13.

\title{
A glance at the prevalence of coronavirus disease 19 (COVID-19) in Iran: Strengths and weaknesses
}

\author{
Nima Mohammadzadeh $\mathrm{PhD}^{1}$, Mahla Shahriary $\mathrm{MSc}^{2}$, Neda Shirmohammadlou MSc ${ }^{3}$ and Vahid Lohrasbi PhD ${ }^{4,5}$ \\ ${ }^{1}$ Department of Microbiology, Faculty of Science, Shahid Beheshti University, Tehran, Iran, ${ }^{2}$ Department of Microbiology, Faculty of Medicine, Tarbiat Modares \\ University of Medical Sciences, Tehran, Iran, ${ }^{3}$ Department of Microbiology, Faculty of Medicine, Zanjan University of Medical Sciences, Zanjan, Iran, ${ }^{4}$ Student \\ Research Committee, Iran University of Medical Sciences, Tehran, Iran and ${ }^{5}$ Department of Microbiology, Faculty of Medicine, Iran University of Medical Sciences, \\ Tehran, Iran
}

To the Editor-After epidemics of severe acute respiratory syndrome-related coronavirus (SARS) in 2002 and Middle East respiratory syndrome-related coronavirus (MERS) in 2012, the third global challenge from a coronavirus began at the end of 2019 , but this time in the form of a pandemic. ${ }^{1}$ The coronavirus disease 2019 (COVID-19) is a respiratory tract infection caused by a virus closely related to the SARS virus called severe acute

Author for correspondence: Vahid Lohrasbi, E-mail: vahidlohrasbi@yahoo.com or lohrasbi.v@tak.iums.ac.ir.

Cite this article: Mohammadzadeh N, et al. (2020). A glance at the prevalence of coronavirus disease 19 (COVID-19) in Iran: Strengths and weaknesses. Infection Control \& Hospital Epidemiology, 41: 1479-1482, https://doi.org/10.1017/ice.2020.193 respiratory syndrome coronavirus 2 (SARS-CoV-2). According to the World Health Organization (WHO) guideline, patients with COVID-19 have symptoms ranging from mild respiratory illness (respiratory symptoms, fever, cough, shortness of breath, and breathing difficulties) to severe (pneumonia, acute respiratory distress syndrome, kidney failure, and death). ${ }^{1}$ Based on scientific reports, ${ }^{2}$ this pandemic began in Wuhan City, China, and quickly spread throughout the country. As of March 15, China has confirmed 81,048 cases with 3,204 deaths. Although the COVID-19 incidence has declined sharply since February 13, 2020, in China, the prevalence increased faster in other countries than scientists anticipated. Italy, with 21,157 positive cases and 
Table 1. List of All Actions Taken in Iran by Date and Category

\begin{tabular}{|c|c|}
\hline Date & Policy and/or Action \\
\hline 19 Feb & $\begin{array}{l}\text { - Established contagious disease management and control teams in Qom province } \\
\text { - Assigned a hospital in Qom for influenza-like illness } \\
\text { - Equipped negative pressure isolation section for isolation of suspicious cases }\end{array}$ \\
\hline $20 \mathrm{Feb}$ & - Increased the production capacity of the mask to 1.2 million units per day \\
\hline 21 Feb & $\begin{array}{l}\text { - Established the "Corona Virus Headquarters and Prevention" at the Ministry of Health } \\
\text { - Obtained the "COVID-19 Laboratory Special Kit" from the World Health Organization } \\
\text { - Inspected Tehran and Qom pharmacies to prevent hoarding }\end{array}$ \\
\hline 22 Feb & $\begin{array}{l}\text { - Increased the production capacity of the face mask by working around the clock } \\
\text { - Prohibited mask exports until further notice } \\
\text { - Began daily disinfection of public transportation and their stations } \\
\text { - Entered educational hospitals affiliated with medical universities to accelerate service delivery }\end{array}$ \\
\hline $23 \mathrm{Feb}$ & $\begin{array}{l}\text { - Supreme leader of Iran and Shia and Sunni Islam authorities start to help Ministry of Health } \\
\text { - Prohibited hookah supplies } \\
\text { - Cancelled student group programs }\end{array}$ \\
\hline $24 \mathrm{Feb}$ & $\begin{array}{l}\text { - Formed "the National Headquarters for Coronavirus" by president of Iran } \\
\text { - Changed all exam dates }\end{array}$ \\
\hline $25 \mathrm{Feb}$ & $\begin{array}{l}\text { - Enlisted students and professors of pharmacy to make disinfectant solution } \\
\text { - Enlisted the Army to help the Ministry of Health } \\
\text { - Closed all centers for the celebration of the bride and groom until secondary notice }\end{array}$ \\
\hline 26 Feb & - Received 5,000 COVID-19 detection kits and masks from China \\
\hline 27 Feb & $\begin{array}{l}\text { - Increased imports of all kinds of masks, gloves, and medical clothes } \\
\text { - Increased travel restrictions } \\
\text { - Began distributing disinfecting gels at } 700 \text { pharmacies in Tehran }\end{array}$ \\
\hline 28 Feb & $\begin{array}{l}\text { - Increased medical alcohol production }>3 \text { times } \\
\text { - Discovered a warehouse with } 6 \text { million gloves in Tehran by the Ministry of Intelligence }\end{array}$ \\
\hline 29 Feb & $\begin{array}{l}\text { - The COVID-19 Surveillance Guideline was released by the Ministry of Health } \\
\text { - Set up an answering center to answer questions about COVID-19 } \\
\text { - Allocated } 2 \text { billion rials (US\$47,500) to the Ministry of Health }\end{array}$ \\
\hline $1 \mathrm{Mar}$ & - Equipped the Pasteur Institute of Iran for daily 12,000 detection test of COVID-19 \\
\hline 2 Mar & $\begin{array}{l}\text { - Enlisted police to help Ministry of Health with full capacity } \\
\text { - Controlled and reduced traffic congestion in cities using police }\end{array}$ \\
\hline 4 Mar & $\begin{array}{l}\text { - Special regulations for filling stations, restaurants, and public places } \\
\text { - Abolition of prayer in all provinces }\end{array}$ \\
\hline 5 Mar & - Launched patient self-assessment and registration system \\
\hline 6 Mar & - Began providing daily 4,000 isolation uniforms for the treatment staff \\
\hline 7 Mar & - Sent 300 million test messages (SMS) from the Ministry of Health for prevention and health care \\
\hline $8 \mathrm{Mar}$ & - Temporarily closed of all places of worship and pilgrimage \\
\hline 9 Mar & $\begin{array}{l}\text { - Started clinical trial of Iranian COVID-19 drugs } \\
\text { - Began checking the body temperature of all people at the entrances of public and nongovernmental centers and at the entrances and } \\
\text { exits of cities } \\
\text { - Printed and distributed brochures of "Environmental Control Guide to Combat COVID-19" in mass population centers (prisons, garrisons, } \\
\text { and military and law enforcement centers), bus stations, train stations, and airport stations } \\
\text { - Printed and distributed brochures of "Mental Health Guide in Crisis" to manage personal stress }\end{array}$ \\
\hline $11 \mathrm{Mar}$ & - Called all volunteer doctors and paramedics to dispatch them to areas in need \\
\hline 13 Mar & $\begin{array}{l}\text { - Issued order to build special healthcare facilities for patients with COVID-19 } \\
\text { - Issued immediate import instructions for medical equipment and supplies and bypassing US sanctions }\end{array}$ \\
\hline $14 \mathrm{Mar}$ & $\begin{array}{l}\text { - Launched new coronavirus detection laboratory at the Pasteur Institute of Iran } \\
\text { - Issued new restrictions on intercity traffic } \\
\text { - Launched telephone psychological services }\end{array}$ \\
\hline 15 Mar & $\begin{array}{l}\text { - Began delivery of thousands of } 250,000 \mathrm{~L} \text { disinfectant to medical universities } \\
\text { - Launched the largest production line of N95 respirators and surgical masks in Iran by Ministry of Defense and Armed Forces Logistics }\end{array}$ \\
\hline $16 \mathrm{Mar}$ & - Established a nursing care center after discharge of patients with a 780-bed capacity in Qom province \\
\hline
\end{tabular}




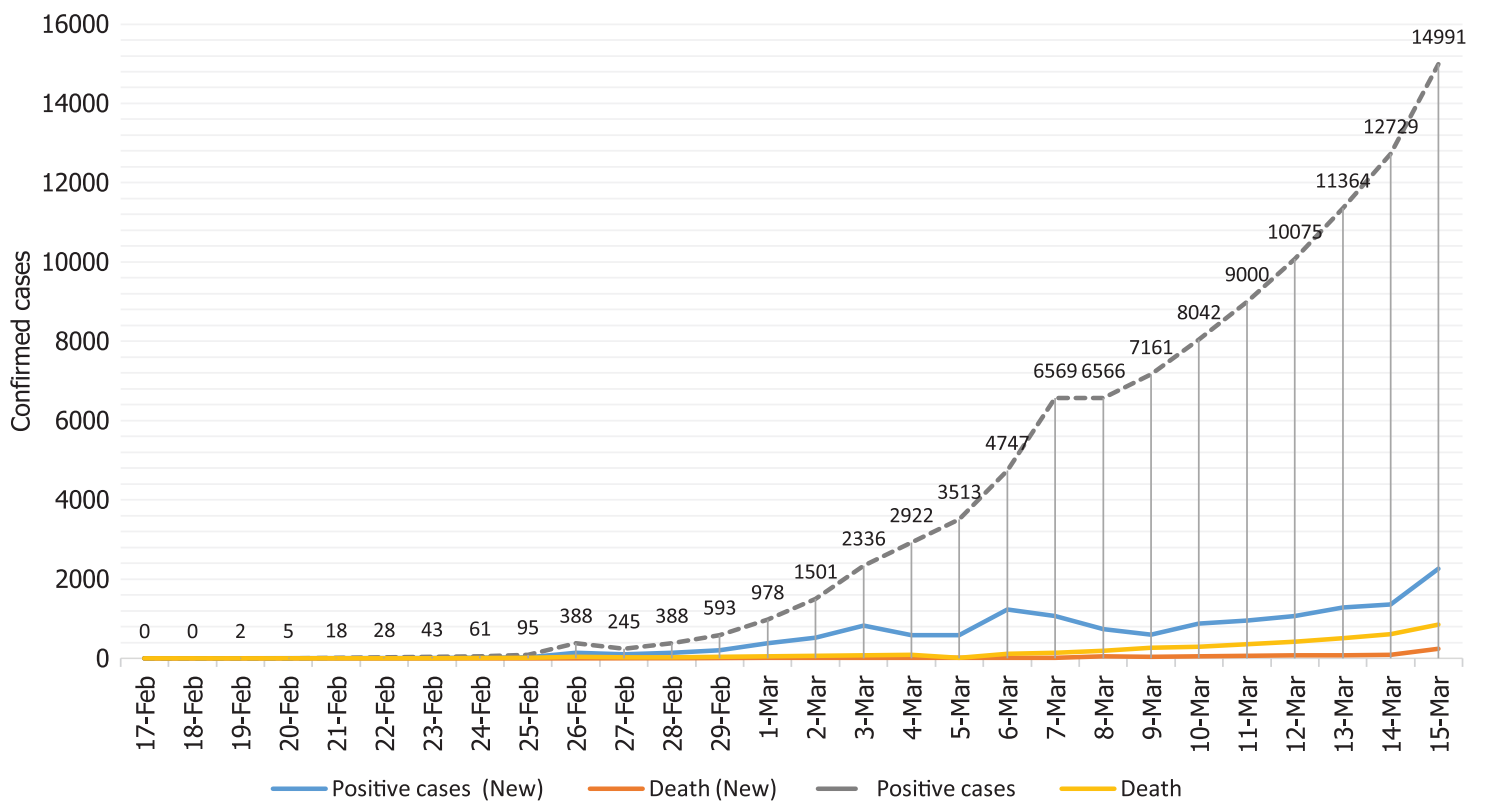

Fig. 1. COVID-19 prevalence in Iran.

1,441 deaths (case fatality rate [CFR], 6.81\%), and South Korea with 8,162 positive cases and 75 death (CFR, $0.91 \%$ ), were the countries most affected as of March $15 .^{2}$

In Iran, the first COVID-19 case was identified on February 19, 2020, in Qom. As of March 16, 2020, 14,991 COVID-19 cases with 853 deaths (CFR, 5.69\%) have been reported cumulatively from all 29 provinces of Iran. Among these states, Tehran has shown the highest incidence, with 3,774 positive cases. ${ }^{2}$ Although Iran has achieved more success in controlling and preventing patient deaths than some developed countries, such as Italy (CFR, 6.81\%), Iran has faced some difficulties in controlling this epidemic. Thus, achieving success and overcoming COVID-19 in Iran requires that we understand these deficiencies.

Some of the most effective actions in Iran in the early days of the COVID-19 outbreak included the following: (1) encouraging people to stay home, (2) providing free diagnostic and therapeutic services to COVID-19 patients, (3) allocating at least 1 hospital in each province to providing special services to COVID-19 patients, (4) daily disinfecting public transportation like subways, buses, and taxis, (5) canceling sport competitions, cinemas, theaters, weddings, and funerals, and closing all schools and universities, (6) providing distance and online learning infrastructure for students (7) increasing the capacity of the production of masks and disinfectants by $>7$ times, (8) extensively informing and promoting a culture of healthcare by the Islamic Republic of Iran Broadcasting system and other media, and launching mobile software, websites and telephone answering systems to address concerns and questions about COVID-19, (9) encouraging people to eat homemade healthy foods instead of fast food, (10) mobilizing and recruiting all national government and nongovernmental organizations to fight COVID-19 under the auspices of "The National Headquarters for Coronavirus," (11) governmental support of small and large businesses to compensate for the loss of revenue and jobs, and finally (12) publication of a COVID-19 surveillance guideline by the Ministry of Health for various organizations (eg, prisons, barracks, etc) to stop and reverse the growing epidemic trend (Table 1). ${ }^{2,3}$

Iran has established an acceptable track record in the control of infectious diseases; but it still has very big challenges to reach an ideal level. These challenges include the following ${ }^{2,4}$ : (1) imposition of travel restrictions by the government on religious cities, like Mashhad and Qom, is difficult; (2) approaching ancient Nowruz ceremonies, like Christmas, are traditionally associated with shopping and large gatherings of people; (3) a failure to quarantine the first city with positive cases of COVID-19 (Qom) with subsequent spread of infection to most provinces of Iran was hampered by the Islamic Consultative Assembly election of 2020 and lack of cooperation by the people; (4) lack of attention by the people to government warnings about travel to Gilan, Mazandaran, and Golestan provinces (popular holiday destinations in Iran) after the closure of schools and universities to aid in spreading the infection; (5) lack of money, medical equipment, and laboratory diagnostic kits because of international sanctions; (6) hoarding of medical devices such as gloves, masks, and disinfectants by profiteers; and (7) lack of space for the quarantine of people with suspected infection in the early days of the outbreak.

Finally, the number of cases in Iran places it in the statistical middle of the COVID-19 outbreak countries (Fig. 1). If Iran tries to overcome to all challenges that are described above, it will be able to manage this crisis. We daresay that "where there's a will, there's a way," and we hope that these challenges will be overcome soon.

Acknowledgments. None.

Financial support. No financial support was provided relevant to this article.

Conflicts of interest. All authors report no conflicts of interest relevant to this article. 
Supplementary material. To view supplementary material for this article, please visit https://doi.org/10.1017/ice.2020.193

\section{References}

1. Li Q, Guan X, Wu P, et al. Early transmission dynamics in Wuhan, China, of novel coronavirus-infected pneumonia. N Engl J Med 2020;382:1199-1207.

2. Iran Ministry of Health and Medical Education website. http://behdasht. gov.ir/. Accessed May 4, 2020.
3. Patel A, Jernigan DB. Initial public health response and interim clinical guidance for the 2019 novel coronavirus outbreak-United States, December 31, 2019-February 4, 2020. Morbid Mortal Wkly Rep 2020;69:140.

4. Lohrasbi V, Mohammadzadeh N, Shirmohammadlou N. Brief outcome of five decades of battle with infectious diseases in Iran. Virusdisease 2020; 31(1):10-12.

\title{
To alert coinfection of COVID-19 and dengue virus in developing countries in the dengue-endemic area
}

\author{
Di Wu MPH ${ }^{1, a}\left(\mathbb{C}\right.$, Jianyun Lu MPH ${ }^{1, a}$, Qun Liu MPH ${ }^{1, a}$, Xiaowei Ma MPH ${ }^{1, a}$ and Weiyun He BSc ${ }^{1}$ \\ ${ }^{1}$ Guangzhou Center for Disease Control and Prevention, Guangzhou, China
}

To the Editor-The SARS-CoV-2 outbreak has raised serious concerns worldwide. The World Health Organization (WHO) has raised the risk of spread to very high level, and as of March 30,2020 , a total of 634,835 cases had been reported, including 29,891 deaths. ${ }^{1}$ Gabriel Yan et al $^{2}$ reported 2 cases of COVID-19 patients coinfected with dengue fever in Singapore. The cases shared similar diagnoses and disease courses. They both first tested negative for dengue using a rapid test, then they were discharged and returned to the hospital for persistent fever and were then diagnosed with dengue fever and SARS-CoV-2 coinfection. Joob et $\mathrm{al}^{3}$ also reported a patient coinfected with SARS-CoV-2 and dengue virus in Thailand. This patient first presented with a with petechiae skin rash and was diagnosed with dengue fever. However, the patient further presented with respiratory symptoms and was rediagnosed with COVID-19 infection. These 3 cases raise concern that patients with fever can be infected with both SARS-CoV-2 and dengue at the same time in dengue-endemic areas such as Singapore, Thailand, and Malaysia in Southeast Asia and Brazil in South America. According to a recent study of 1,099 patients conducted by Guan et $\mathrm{al}^{4}{ }^{4} 87.9 \%$ of COVID-19 patients present with fever, $67.7 \%$ present with cough, and $13.7 \%$ present with headache. Some patients present only with fever when infected with SARS-CoV-2. In another study of 1,792 patients, $100 \%$ of dengue fever patients presented with fever and $25.7 \%$ presented with headache. ${ }^{5}$ Thus, COVID-19 patients can present the same clinical signs as dengue patients. Furthermore, the Singapore cases were misdiagnosed and later confirmed with COVID-19, ${ }^{2}$ which shows that the misdiagnosis of the patients with atypical symptoms (as listed above) is possible. Therefore, measures should be taken to distinguish patients with fever and headache from dengue fever and COVID-19, and these atypical symptoms should trigger alerts, especially in developing countries with a high incidence of dengue fever, as in Southeast
Asia and South American. We strongly recommend that rapid, sensitive, and accessible tests include a polymerase chain reaction (PCR) test of nasopharynx swabs and anal swabs. Furthermore, dengue NS1, IgM, and IgG tests should be used to distinguish those with atypical symptoms in the developing countries facing the coming dengue endemic.

\section{Acknowledgments.}

Financial support. This work was supported by the National Natural Science Foundation of China (grant no. 81803325), the Medical Science and Technology Project of Guangzhou (grant nos. 20191A011064 and 20201A011067), and the Guangdong Medical Science and Technology Research Project (grant no. A2019379).

Conflicts of interest. All authors report no conflicts of interest relevant to this article.

\section{References}

1. Coronavirus disease 2019 (COVID-19) Situation Report - 69. World Health Organization. https://www.who.int/emergencies/diseases/novelcoronavirus-2019/situation-reports/. Published March 29, 2020. Accessed March 30, 2020.

2. Yan G, Lee CK, Lam LTM, et al. Covert COVID-19 and false-positive dengue serology in Singapore. Lancet Infect Dis 2020 Mar 4 [Epub ahead of print] doi: 10.1016/S1473-3099(20)30158-4.

3. Joob B, Wiwanitkit V. COVID-19 can present with a rash and be mistaken for Dengue. J Am Acad Dermatol 2020 [Epub ahead of print]. doi: 10.1016/j.jaad. 2020.03.036.

4. Guan WJ, Ni ZY, Hu Y, et al. Clinical characteristics of coronavirus disease 2019 in China. N Engl J Med 2020;382:1708-1720.

5. Chen D, Zhang Y, Wu X, et al. A survey of clinical and laboratory characteristics of dengue fever epidemic from 2014 to 2018 in Guangzhou, China. Ann Palliat Med 2020;9:70-81.

\footnotetext{
Author for correspondence: Weiyun He, E-mail: cloudhe@21cn.com

${ }^{a}$ Authors of equal contribution.

Cite this article: Wu D, et al. (2020). To alert coinfection of COVID-19 and dengue virus in developing countries in the dengue-endemic area. Infection Control \& Hospital Epidemiology, 41: 1482, https://doi.org/10.1017/ice.2020.187
}

(c) 2020 by The Society for Healthcare Epidemiology of America. All rights reserved This is an Open Access article, distributed under the terms of the Creative Commons Attribution licence (http://creativecommons.org/licenses/by/4.0/), which permits unrestricted re-use, distribution, and reproduction in any medium, provided the original work is properly cited. 